\title{
Crops of Waxy Purple Corn: A Valuable Source of Antioxidative Phytochemicals
}

\author{
Suthasinee Thapphasaraphong ${ }^{1 *}$, Thithima Rimdusit ${ }^{1}$, Aroonsri Priprem ${ }^{2}$, Ploenthip Puthongking ${ }^{1}$
}

\begin{abstract}
Crops of waxy purple corn (Zea mays L. ceritina Kulesh., PC), a hybrid corn variety rich in anthocyanin contents, provide abundant waste byproducts from its cobs (PCC), silks (PCS), husks $(\mathrm{PCH})$, and pollens (PCP), of which phytochemicals and antioxidative activities being determined. Each byproduct was be subjected to extracted by maceration and separation from various solvents. All PC byproducts contained carbohydrates, tannins, flavonoids, and anthocyanins. Thin layer chromatography reported cyanidin-3-glucoside $(\mathrm{C} 3 \mathrm{G})$ as the major anthocyanins of PCC and $\mathrm{PCH}$. Hydro-ethanolic extracts (HE) of PCS gave the highest level of phenolic compound of $357 \mathrm{mg} \mathrm{GAE} / \mathrm{g}$, while that of $\mathrm{PCH}$ gave the highest anthocyanin contents of $0.11 \mathrm{mg} \mathrm{C} 3 \mathrm{G} / \mathrm{g}$. DPPH, ABTS, and FRAP assays were used to compare all extracts of PC byproducts. $\mathrm{HE}$ of $\mathrm{PCH}$ and PCS provided the best ABTS values of 328 and 328 $\mathrm{mg} \mathrm{TEAC} / \mathrm{g}$, respectively, and also the strongest DPPH radical scavenging of $365 \mathrm{mg} \mathrm{TEAC/g}$. Aqueous extracts of PCC gave the highest FRAP value with $800 \mathrm{mg} \mathrm{Fe}(\mathrm{II}) / \mathrm{g}$. It is concluded that these byproducts of PC could provide high yield of valuable phytochemicals with antioxidative potentials for use in health products.
\end{abstract}

Keywords - Waxy purple corn cobs, Waxy purple corn silks, Anthocyanins, Antioxidant activities, Phytochemicals.

\section{INTRODUCTION}

$\mathrm{A}$ NTHOCYANINS are the natural pigment compounds, which provided red, blue, and purple color in plants and flowers; such as, raspberry, mulberry, grape, and purple corn. They are water-soluble phenolic compounds as known as their chemical structures gives highly potential in ability of free radical scavenging. Their types and antioxidant abilities depend on their chemical structures, especially the numbers of methoxyl $\left(\mathrm{OCH}_{3}\right)$ and hydroxyl $(\mathrm{OH})$ substitute groups exist in their molecules [10]. Furthermore, there are many publications reported other biological activities of anthocyanin besides their antioxidant activity; for example, decreasing of blood sugar level, reducing of blood cholesterol level, and vision improvement [6].

Purple corn (Zea mays L.) is originated from Andes Mountain, Peru. Mostly it was used as food, and food colorant. Nowadays, purple corn had been developed breeding for survival improvement. It contains rich of anthocyanin and polyphenol contents $[11,19]$. A waxy purple corn variety (PC) was developed to serve the local customers' preferences, i.e.

\footnotetext{
${ }^{1}$ Department of Pharmaceutical Chemistry, Faculty of Pharmaceutical Sciences, Khon Kaen University, 40002, Thailand.

${ }^{2}$ Department of Pharmaceutical Technology, Faculty of Pharmaceutical Sciences, Khon Kaen University, 40002, Thailand.
}

taste and texture, by the Plant Breeding Research Center for Sustainable, Faculty of Agriculture, Khon Kaen University. It appears to have dark color throughout its cops (PCC), husks $(\mathrm{PCH})$, pollens (PCP) and silks (PCS), which were thought to be agricultural wastes. However, it was thought to be able to turn the wastes into valuable byproducts as the pigments of these byproducts were assumed to be anthocyanins. In addition, some studies were reported that high anthocyanin contents were also found in cobs, silks, husks, and leaves of purple corn $[7,12,13]$. The anthocyanin constituents in ethanolic purple corn extract were identified by using LC/ESI/MS showed the results that there were found 8 anthocyanins; there are cyanidin-3-glucoside, pelargonidin-3glucoside, peonidin 3-glucoside, cyanidin-3-(6") malonylglucoside), pelargonidin-3-(6',-malonylglucoside), cyanidin-3-(6',-dimalonylglucoside), peonidin-3-(6"'malonylglucoside), and cyanidin-3-O-(6',-acetylglucoside) and cyanidin-3-glucoside showed the highest amount of total anthocyanin contents [8]. Recently, many researches have been reported biological abilities and therapeutic effects of purple corn extracts. The best potential of biological activity is antioxidant activities were supported by the study of [20] reported that antioxidant determination assays (TEAC, DPPH, and FRAP assays) of anthocyanin purple corn cobs and corn seeds extracts were significantly better than butylated hydroxytoluene $(\mathrm{BHT})(\mathrm{p}<0.05)$. In the same time, purple corn anthocyanins extract mixed with animal diet showed decreasing of oxidative stress via SOD level increment in sheep's plasma [5]. Next, ethanolic seed extract of purple corn extract can reduce blood glucose level (FPG and OGTT) in $\mathrm{db} / \mathrm{db}$ mice plasma by directly stimulate insulin secretion (\% HbA1C) while it can protect the death of hamster pancreatic beta cell line (HIT- T15) occurring from using glimpiride, diabetes metallitus type 2 medicine in sulfonylurea group [4]. Furthermore cyanidin-3-glucoside and pelargodin-3-glucoside, types of anthocyanin found in PCA, showed inhibition of tumor cell from androgen-dependent cell line (LNCaP) in rat [9].

To enable the use of the under-utilized byproducts of the PC, phytochemical constituents and types of anthocyanin were qualitatively analyzed. The byproducts from the waxy purple corn, i.e. cobs, silks, husk, and pollens were selected as the abundant with potential sources. Evaluation of total phenolic compounds, total anthocyanin contents and antioxidant activities could provide fundamental information for selection for use in health products. If any of the byproduct(s) is found to be rich in valuable phytochemicals, crop harvesting of the $\mathrm{PC}$ could have additional values in the future. 


\section{MATERIALS AND METHODS}

\section{A. Materials}

Byproducts (cobs, silks, husks, and pollens) of waxy purple corn was provided by the Plant Breeding Research Center for Sustainable, Faculty of Agriculture, Khon Kaen University from a harvesting crop in 2014. 2,2'-azino-bis-(3ethylbenzothiazoline-6 sulfonic acid) (ABTS), 2,4,6 Tris (2pyridyl)-s-triazine (TPTZ), 2,2-diphenyl-1-picrylhydrazyl (DPPH), 6-hydroxy 2,5,7,8-tetramethylchromane-2 carboxylic acid (Trolox), Cyanidin-3-glucoside (C3G), Peonidin-3glucoside (Pn3G), and Pelargonidin-3-glucoside (Pg3G) standards were purchased from Sigma-Aldrich (Missouri, USA) Gallic acid was purchased from Merck (Darmstadt, Germany). Folin-Ciocalteu's phenol reagent was obtained from ERBApharm (Peypin, France). All chemicals used were analytical grades.

\section{B. Methods}

\section{a. Sample preparation}

Pulverized PCC, PCH, PCP and PCS were 24-hrs macerated with stirring at $25^{\circ} \mathrm{C}$ in water $(\mathrm{H})$, ethanol (E), methanol (M), $50 \%$ ethanol in water (HE) or $50 \%$ methanol in water (HM) at a ratio of 1:25. The filtrate was separated and the residues were repeatedly extracted. All filtrate were rotary evaporated and then freeze-dried to be crude extracts which were lightprotected stored at about $4^{\circ} \mathrm{C}[19]$.

\section{b. Phytochemicals}

The liquid extracts of the samples were subjected to these screening for phytochemicals, as follows: Molisch's test for carbohydrates, foaming for saponins, Dragendorff's and Mayer's reagents for alkaloids, ferric chloride reagent for gallic or catecholic tannins, Shinoda's color tests lead acetate for flavonoids and Fehling's reagent for free reducing sugar. Powder samples were treated with $2 \mathrm{M} \mathrm{NaOH}$ to observe bluegreen color for screening of the presence of anthocyanins $[1,2,16,17,18]$.

c. Thin Layer Chromatography (TLC) method

TLC for qualitative determination of anthocyanins was, as follows: the samples on the silica gel TLC plate $(1 \mathrm{~mm}$ thick, Merck, Germany) were eluted with a mixture of ethyl acetate, glacial acetic acid, formic acid, and water (at a volume ratio of 100:11:11:26) was compared for reference bands of the standards of $1 \mathrm{mg} / \mathrm{ml}$ of anthocyanin standards were prepared in methanol [14].

\section{d. Total phenolic compound (TPC)}

Total phenolic compound was measured according to modified methods of $[3,21]$. Briefly, gallic acid standard or sample $15 \mu \mathrm{l}$ was added to 96 -well microplate to mix with 85 $\mu \mathrm{l}$ of Folin-Ciocaluteu reagent which prepared by diluting ten times with water, followed by addition of $7 \%$ sodium carbonate $100 \mu \mathrm{l}$, then left for 90 minutes in the dark with room temperature. The absorbance was measured at $700 \mathrm{~nm}$ by using microplate reader. The results were expressed as $\mathrm{mg}$ gallic acid equivalent (GAE)/g of sample. All samples were triplicate tested.

\section{e. Antioxidant activities}

DPPH for free radical scavenging ability was conducted by mixing equal volume of trolox or samples with $0.4 \mathrm{mM} \mathrm{DPPH}$ in methanol and allowing $30 \mathrm{~min}$ reaction in the dark at room temperature. Absorbance of the reactants was recorded at 517 $\mathrm{nm}$ using a microplate reader [20]. ABTS assay to determine antiradical activity. The $\mathrm{ABTS}^{\circ+}$ solution was prepared by mixing $7.0 \mathrm{mM}$ ABTS with $4.95 \mathrm{mM}$ potassium persulfate in a volume ratio of $1: 1$, which was incubated in the dark for $16 \mathrm{~h}$ at room temperature. An appropriate proportion of trolox or samples were reacted with the $\mathrm{ABTS}^{\circ+}$ solution in the dark for $30 \mathrm{~min}$ and the absorbance at $700 \mathrm{~nm}$ was measured using a microplate reader [20]. The percentage of scavenging from DPPH and ABTS was calculated. All of the results were expressed as $\mathrm{mg}$ trolox equivalent antioxidant capacity (TEAE)/g by comparing the concentration of the standard (trolox) with the samples at $50 \%$ scavenging of free radicals.

FRAP assay to measure reducing ability of $\mathrm{Fe}^{3+}$-TPTZ complex to $\mathrm{Fe}^{2+}$-TPTZ complex, using a volume ratio of 10:1:1 of acetate buffer at $\mathrm{pH} 3.6: 20 \mathrm{mM}$ Ferric chloride : 10 $\mathrm{mM}$ TPTZ/40 $\mathrm{mM} \mathrm{HCl}$ as the reagent. $10 \%$ of ferrous sulfate standard or samples in the reagent was reacted in the dark for $30 \mathrm{~min}$ at room temperature and its absorbance recorded at $593 \mathrm{~nm}$ using a microplate reader. Triplicates were averaged and expressed as $\mathrm{mg}$ Fe (II)/ g sample [20].

f. 2.2.6 Total anthocyanin contents (TAC)

Total anthocyanin contents were determined by using $\mathrm{pH}-$ differential method according to [20] with slightly modification. Briefly, the sample $5 \mathrm{mg}$ was mixed with $1 \mathrm{ml}$ of $0.025 \mathrm{M}$ potassium chloride buffer $(\mathrm{pH}$ 1.0) and another sample $5 \mathrm{mg}$ was mixed with $1 \mathrm{ml}$ of $0.025 \mathrm{M}$ sodium acetate buffer ( $\mathrm{pH} 4.5$ ). Then, sample solutions were added into 96well microplate $200 \mu \mathrm{l}$. The absorbance was measured wavelength at 510 and $700 \mathrm{~nm}$ by using UV-Visible microplate reader. All samples were triplicate tested. The results were expressed as $\mathrm{mg} \mathrm{C} 3 \mathrm{G} / 100 \mathrm{~g}$ sample unit.

\section{Statistical analysis}

The data was analyzed by using SPSS version 11.0 (SPSS Inc., USA), which consisted of descriptive analysis and comparative analysis (one-way analysis of variance). Then, Post Hoc test were used to analyze differences between groups. The correlation was also analyzed (Pearson correlation).

\section{RESULTS AND DISCUSSION}

TABLE I

THE PERCENTAGE YIELDS OF EXTRACTS WAXY PURPLE CORN CROPS WITH VARIOUS EXTRACTING SOLVENTS

\begin{tabular}{lcccc}
\hline \hline \multirow{2}{*}{ Extraction Solvent } & \multicolumn{4}{c}{ Total yield (\%W/W) } \\
\cline { 2 - 5 } & Cob & Silk & Husk & $\begin{array}{c}\text { Polle } \\
\text { n }\end{array}$ \\
\hline Water (H) & 7.94 & 14.6 & 7.45 & 14.06 \\
Ethanol (E) & 3.24 & 3.35 & 3.41 & 4.95 \\
Methanol (M) & 6.68 & 8.68 & 7.43 & 19.17 \\
50\% ethanol (HE) & 10.3 & 17.2 & 11.8 & 15.69 \\
50\% methanol & 0 & 0 & 7 & \\
(HM) & 9.25 & 15.1 & 11.3 & 20.76 \\
\hline \hline
\end{tabular}


Table 1 compares percentage yields of the PC byproducts extracts and suggests that PCP gave the highest yields, especially HE and HM extracts. Table 2 shows the results from qualitative analysis of phytochemical screening, all extracts shows the presence of carbohydrates, tannins, flavonoids, and anthocyanin compounds. In addition TLC

TABLE II

PHYTOCHEMICAL SCREENING OF COB, SILK, HUSK, AND POLLEN FROM WAXY PURPLE CORN EXTRACTS

\begin{tabular}{|c|c|c|c|c|c|c|c|c|c|c|}
\hline \multirow[b]{3}{*}{ Part } & \multirow{3}{*}{$\begin{array}{c}\text { Extraction } \\
\text { Solvent }\end{array}$} & & & & & & & & & \\
\hline & & \multicolumn{9}{|c|}{ Test* } \\
\hline & & $\mathbf{M o}^{1}$ & $\mathbf{D}^{2}$ & Ma & Foam & $\mathrm{NaOH}$ & $\begin{array}{c}\mathrm{FeCl} \\
3\end{array}$ & Feh & Shi & $\mathbf{P b}$ \\
\hline \multirow{5}{*}{$\begin{array}{c}\text { Cob } \\
(\mathbf{P C C})\end{array}$} & $\mathrm{H}$ & + & - & - & - & + & ++ & - & + & + \\
\hline & $\mathrm{E}$ & ++ & - & - & - & + & +++ & - & ++ & ++ \\
\hline & $\mathrm{M}$ & ++ & - & - & - & + & +++ & - & ++ & ++ \\
\hline & $\mathrm{HE}$ & ++ & - & - & - & + & +++ & - & $\begin{array}{c}++ \\
+\end{array}$ & $\begin{array}{c}++ \\
+\end{array}$ \\
\hline & $\mathrm{HM}$ & ++ & - & - & - & + & +++ & - & $\begin{array}{c}++ \\
+\end{array}$ & $\begin{array}{r}++ \\
+\end{array}$ \\
\hline \multirow{5}{*}{$\begin{array}{c}\text { Silk } \\
\text { (PCS) }\end{array}$} & $\mathrm{H}$ & + & - & - & - & + & +++ & - & $\begin{array}{c}++ \\
+\end{array}$ & $\begin{array}{r}++ \\
+\end{array}$ \\
\hline & $\mathrm{E}$ & + & - & - & - & + & + & - & + & + \\
\hline & $\mathrm{M}$ & + & - & - & - & + & +++ & - & ++ & + \\
\hline & $\mathrm{HE}$ & + & - & - & - & + & +++ & - & $\begin{array}{c}++ \\
+\end{array}$ & $\begin{array}{c}++ \\
+\end{array}$ \\
\hline & $\mathrm{HM}$ & + & - & - & - & + & +++ & - & $\begin{array}{c}++ \\
+\end{array}$ & $\begin{array}{c}++ \\
+\end{array}$ \\
\hline \multirow{5}{*}{$\begin{array}{l}\text { Husk } \\
\text { (PCH) }\end{array}$} & $\mathrm{H}$ & + & - & - & - & + & +++ & - & ++ & ++ \\
\hline & $\mathrm{E}$ & + & - & - & - & + & + & - & + & + \\
\hline & $\mathrm{M}$ & ++ & - & - & - & + & +++ & - & ++ & ++ \\
\hline & HE & + & - & - & - & + & +++ & - & $\begin{array}{c}++ \\
+\end{array}$ & $\begin{array}{c}++ \\
+\end{array}$ \\
\hline & $\mathrm{HM}$ & ++ & - & - & - & + & +++ & - & $\begin{array}{c}++ \\
+\end{array}$ & $\begin{array}{c}++ \\
+\end{array}$ \\
\hline \multirow{5}{*}{$\begin{array}{l}\text { Pollen } \\
\text { (PCP) }\end{array}$} & $\mathrm{H}$ & + & - & - & - & + & + & - & + & + \\
\hline & $\mathrm{E}$ & ++ & - & - & - & + & + & - & - & + \\
\hline & $\mathrm{M}$ & ++ & - & - & - & + & + & - & - & + \\
\hline & $\mathrm{HE}$ & ++ & - & - & - & + & ++ & - & ++ & ++ \\
\hline & HM & ++ & - & - & - & + & ++ & - & ++ & ++ \\
\hline
\end{tabular}

*Molisch's test (Mo), Dragendorff's test (D), Mayer's test (M), Foam test (Foam), NaOH test (NaOH), $\mathrm{FeCl}_{3}$ test $\left(\mathrm{FeCl}_{3}\right)$, Fehling's test (Feh), Shinoda's test (Shi), Lead acetate test $(\mathrm{Pb})$ used to identify types of anthocyanin in each extracts. TLC results showed $\mathrm{R}_{\mathrm{f}}$ values from every extraction solvents of PCC and PCH were consisted of C3G (0.48), Pn3G (0.53), and Pg3G (0.58), excepted aqueous extract of $\mathrm{PCH}$ had only $\mathrm{C} 3 \mathrm{G}$ as same as HE and HM of PCS extracts. 
TABLE III

DPPH, ABTS, FRAP, TPC, AND TAC VALUES OF EACH EXTRACT

\begin{tabular}{|c|c|c|c|c|c|c|c|c|c|c|c|c|c|c|c|c|}
\hline \multirow[b]{2}{*}{ Part } & \multirow[b]{2}{*}{$\begin{array}{c}\text { Extraction } \\
\text { Solvent }\end{array}$} & \multicolumn{15}{|c|}{ Assay } \\
\hline & & \multicolumn{3}{|c|}{$\begin{array}{c}\text { DPPH } \\
(\mathrm{mg} \text { TEAC/g) }\end{array}$} & \multicolumn{3}{|c|}{$\begin{array}{c}\text { ABTS } \\
\text { (mg TEAC/g) }\end{array}$} & \multicolumn{3}{|c|}{$\begin{array}{c}\text { FRAP } \\
(\mathbf{m g ~ F e}(\mathbf{I I}) / \mathrm{g})\end{array}$} & \multicolumn{3}{|c|}{$\begin{array}{c}\text { TPC } \\
\text { (mg GAE/g) }\end{array}$} & \multicolumn{3}{|c|}{$\begin{array}{c}\text { TAC } \\
\text { (mg C3G/100 g) }\end{array}$} \\
\hline \multirow{5}{*}{$\begin{array}{l}\text { Cob } \\
\text { (PCC) }\end{array}$} & $\mathrm{H}$ & 174.22 & \pm & $0.58^{\mathrm{a}}$ & 106.82 & \pm & $0.13^{\mathrm{a}}$ & 800.38 & \pm & $10.28^{\mathrm{a}}$ & 141.14 & \pm & $3.98^{\mathrm{a}}$ & 1.24 & \pm & $0.01^{\mathrm{a}}$ \\
\hline & E & 140.41 & \pm & $0.20^{\mathrm{b}}$ & 97.45 & \pm & $0.84^{\mathrm{b}}$ & 304.07 & \pm & $4.49^{\mathrm{b}}$ & 160.30 & \pm & $2.20^{\mathrm{b}}$ & 5.01 & \pm & $0.03^{\mathrm{abcc}}$ \\
\hline & M & 175.04 & \pm & $0.68^{\mathrm{a}}$ & 140.21 & \pm & $0.38^{\mathrm{c}}$ & 465.94 & \pm & $3.12^{\mathrm{c}}$ & 179.37 & \pm & $2.18^{\mathrm{c}}$ & 5.68 & \pm & $0.00^{\mathrm{b}}$ \\
\hline & HE & 256.60 & \pm & $1.42^{\mathrm{c}}$ & 237.50 & \pm & $0.21^{\mathrm{d}}$ & 595.11 & \pm & $1.31^{\mathrm{d}}$ & 266.88 & \pm & $2.50^{\mathrm{d}}$ & 7.46 & \pm & $0.05^{\mathrm{c}}$ \\
\hline & HM & 272.86 & \pm & $0.86^{\mathrm{d}}$ & 241.07 & \pm & $0.83^{\mathrm{e}}$ & 475.52 & \pm & $2.66^{\mathrm{c}}$ & 232.41 & \pm & $1.35^{\mathrm{e}}$ & 5.99 & \pm & $0.03^{\mathrm{d}}$ \\
\hline \multirow{5}{*}{$\begin{array}{c}\text { Silk } \\
\text { (PCS) }\end{array}$} & $\mathrm{H}$ & 163.55 & \pm & $1.00^{\mathrm{a}}$ & 124.05 & \pm & $0.49^{\mathrm{a}}$ & 590.4 & \pm & $3.05^{\mathrm{a}}$ & 253.86 & \pm & $3.51^{\mathrm{a}}$ & 1.74 & \pm & $0.05^{\mathrm{a}}$ \\
\hline & E & 63.75 & \pm & $0.35^{\mathrm{b}}$ & 101.79 & \pm & $1.06^{\mathrm{b}}$ & 185.82 & \pm & $0.79^{\mathrm{b}}$ & 116.79 & \pm & $2.77^{\mathrm{b}}$ & 1.18 & \pm & $0.01^{\mathrm{b}}$ \\
\hline & M & 124.50 & \pm & $0.21^{\mathrm{c}}$ & 136.42 & \pm & $0.74^{\mathrm{c}}$ & 275.08 & \pm & $0.59^{\mathrm{c}}$ & 120.80 & \pm & $2.48^{\mathrm{b}}$ & 4.29 & \pm & $0.04^{\mathrm{c}}$ \\
\hline & $\mathrm{HE}$ & 364.45 & \pm & $1.86^{\mathrm{d}}$ & 328.13 & \pm & $2.28^{\mathrm{d}}$ & 660.50 & \pm & $1.96^{\mathrm{d}}$ & 356.96 & \pm & $10.84^{\mathrm{c}}$ & 5.17 & \pm & $0.03^{\mathrm{d}}$ \\
\hline & HM & 312.81 & \pm & $2.86^{\mathrm{e}}$ & 280.63 & \pm & $1.60^{\mathrm{e}}$ & 626.34 & \pm & $2.30^{\mathrm{e}}$ & 309.66 & \pm & $7.25^{\mathrm{d}}$ & 5.16 & \pm & $0.05^{\mathrm{d}}$ \\
\hline \multirow{5}{*}{$\begin{array}{l}\text { Husk } \\
\text { (PCH) }\end{array}$} & $\mathrm{H}$ & 341.14 & \pm & $1.81^{\mathrm{a}}$ & 114.02 & \pm & $0.59^{\mathrm{a}}$ & 603.31 & \pm & $2.34^{\mathrm{a}}$ & 210.98 & \pm & $1.49^{\mathrm{a}}$ & 5.91 & \pm & $0.10^{\mathrm{a}}$ \\
\hline & E & 124.97 & \pm & $0.49^{\mathrm{b}}$ & 111.53 & \pm & $0.56^{\mathrm{a}}$ & 332.97 & \pm & $1.59^{\mathrm{b}}$ & 121.28 & \pm & $1.57^{\mathrm{b}}$ & 6.57 & \pm & $0.03^{\mathrm{b}}$ \\
\hline & M & 164.72 & \pm & $1.46^{\mathrm{c}}$ & 202.82 & \pm & $2.78^{b}$ & 485.00 & \pm & $1.47^{\mathrm{c}}$ & 175.68 & \pm & $1.77^{\mathrm{c}}$ & 8.35 & \pm & $0.01^{\mathrm{c}}$ \\
\hline & $\mathrm{HE}$ & 289.35 & \pm & $2.03^{\mathrm{d}}$ & 328.41 & \pm & $1.91^{\mathrm{c}}$ & 711.78 & \pm & $2.12^{\mathrm{d}}$ & 257.37 & \pm & $5.65^{\mathrm{d}}$ & 10.97 & \pm & $0.18^{\mathrm{d}}$ \\
\hline & $\mathrm{HM}$ & 261.83 & \pm & $1.85^{\mathrm{e}}$ & 317.38 & \pm & $2.23^{\mathrm{d}}$ & 670.90 & \pm & $3.71^{\mathrm{e}}$ & 303.13 & \pm & $4.15^{\mathrm{e}}$ & 9.00 & \pm & $0.08^{\mathrm{e}}$ \\
\hline \multirow{5}{*}{$\begin{array}{l}\text { Pollen } \\
\text { (PCP) }\end{array}$} & $\mathrm{H}$ & 81.05 & \pm & $0.73^{\mathrm{a}}$ & 97.17 & \pm & $1.66^{\mathrm{a}}$ & $\begin{array}{l}81.48 \\
\end{array}$ & \pm & $1.84^{\mathrm{a}}$ & 132.36 & \pm & $0.38^{\mathrm{a}}$ & 0.11 & \pm & $0.00^{\mathrm{abc}}$ \\
\hline & E & 144.35 & \pm & $1.50^{\mathrm{b}}$ & 57.93 & \pm & $0.25^{\mathrm{b}}$ & 96.65 & \pm & $1.32^{\mathrm{b}}$ & 145.55 & \pm & $0.73^{\mathrm{b}}$ & 0.00 & \pm & $0.00^{\mathrm{b}}$ \\
\hline & M & 96.25 & \pm & $0.40^{c}$ & 88.47 & \pm & $2.33^{\mathrm{c}}$ & 107.11 & \pm & $0.18^{\mathrm{c}}$ & 152.71 & \pm & $3.56^{\mathrm{b}}$ & 0.10 & \pm & $0.01^{\mathrm{c}}$ \\
\hline & $\mathrm{HE}$ & 48.46 & \pm & $0.17^{\mathrm{d}}$ & 63.12 & \pm & $0.61^{\mathrm{d}}$ & 133.33 & \pm & $1.08^{\mathrm{d}}$ & 197.69 & \pm & $3.06^{\mathrm{c}}$ & 0.50 & \pm & $0.02^{\mathrm{abcc}}$ \\
\hline & $\mathrm{HM}$ & 68.18 & \pm & $1.40^{\mathrm{e}}$ & 67.79 & \pm & $1.35^{\mathrm{e}}$ & 140.11 & \pm & $0.54^{\mathrm{e}}$ & 254.62 & \pm & $6.22^{\mathrm{d}}$ & 1.08 & \pm & $0.03^{\mathrm{d}}$ \\
\hline
\end{tabular}

Values are mean $(\mathrm{n}=3)$. Values followed by the same letter in the same column (of each part) are not significantly different $(\mathrm{p}<0.05)$.

TABLE IV

CORRELATION COEFFICIENTS FOR LINEAR RELATIONSHIPS BETWEEN TOTAL PHENOLIC COMPOUNDS (TPC), TOTAL ANTHOCYANIN CONTENTS (TAC), AND ANTIOXIDANT ACTIVITIES (DPPH, ABTS, AND FRAP ASSAYS) $(\mathrm{P}<0.5)$

\begin{tabular}{ccccc}
\hline \multirow{2}{*}{ Tests } & \multicolumn{3}{c}{ Correlation coefficient $(\mathbf{r})(\mathbf{n}=3)$} \\
\cline { 2 - 5 } & ABTS & FRAP & TAC & TPC \\
\hline DPPH & $0.802^{*}$ & $0.815^{*}$ & $0.660^{*}$ & $0.665^{*}$ \\
ABTS & & $0.794^{*}$ & $0.841^{*}$ & $0.605^{*}$ \\
FRAP & & & $0.713^{*}$ & $0.579^{*}$ \\
TAC & & & & $0.442^{*}$ \\
\hline \hline
\end{tabular}

*Correlation is significant at the 0.01 level (2-tailed.)

From Table 3, total phenolic compounds (TPC) and total anthocyanin contents (TAC) of the PC byproducts showed that $\mathrm{HE}$ and HM extracts contained higher TPC and TAC than other solvents. PCS extracted with HE showed the highest TPC value was $356.96 \pm 10.84 \mathrm{mg} \mathrm{GAE} / \mathrm{g}$ sample. While PCH in $\mathrm{HE}$ gave TAC of $10.97 \pm 0.18 \mathrm{mg} \mathrm{C} 3 \mathrm{G} / 100 \mathrm{~g}$, which is in line with previous report [7]. The correlation coefficient between TAC and TPC was equal to 0.442 , which indicated that naturally anthocyanins were not only phenolic compounds found in PC. The other phenolic compound influenced to increasing of TPC value while TAC value tends to be constant.

Antioxidant activities by DPPH, ABTS, FRAP assays were found that PCP presented the lowest capacity to eliminate free radical in every assays. Various part and extracted solvent of PC also effect to antioxidant ability of each samples. DPPH and ABTS assays provided similar results that $\mathrm{HE}$ and $\mathrm{HM}$ of all PC parts informed significantly higher free radical scavenging capability $(\mathrm{p}<0.05)$ compared with other extracted solvents. As well as FRAP assay, The PC extracts were extracted from $\mathrm{H}, \mathrm{HE}$, and $\mathrm{HM}$ gave satisfy antioxidant activities. HE extracts of PCH and PCS provided the highest free radical scavenging rates in ABTS assay of 328.41 \pm 1.91 and $328.13 \pm 2.28 \mathrm{mg}$ TEAC/g sample, respectively, also, PCS HE extract showed the strongest DPPH radical scavenging significantly $(\mathrm{p}<0.05)$. While FRAP assay, the aqueous PCC extract gave the best potential of ferric ion reducing rate was equal to $800.38 \pm 10.28 \mathrm{mg} \mathrm{Fe}(\mathrm{II}) / \mathrm{g}$ sample. The correlation coefficients between antioxidant assays, shown in Table 4, confirmed that the byproducts of PC gave antioxidative phytochemicals

\section{CONCLUSION}

All byproducts extractable from the waxy purple corn were rich resources of anthocyanins, particularly $\mathrm{HE}$ and $\mathrm{HM}$ extracts due to semi-polar characteristics of the compounds and the solvents. High potential of free radical scavenging abilities in DPPH, ABTS, and FRAP assays were correlated with the phytochemicals and TAC and TPC. PCC and PCH showed the presence of three major anthocyanin constituents, including $\mathrm{C} 3 \mathrm{G}, \mathrm{Pn} 3 \mathrm{G}$, and $\mathrm{Pg} 3 \mathrm{G}$. Considering the parts of PCS, PCH is the highest interested part because it gave results satisfactorily followed by these reasons; plenty of raw material can be provided, high yield, rich of total phenolic and anthocyanin contents, and strong antioxidant capacity in all assays. Thus, these byproducts are potential for health product development in the future and should provide value adding to the agricultural waste products.

\section{ACKNOWLEDGMENT}

Partial financial supports from Khon Kaen University (Incubation for Researches Project) and Agricultural Research Development Agency (Public Organization) (ARDA) (CRP5605010310), Thailand are acknowledged. Assoc. Prof. Dr. Kamol Lertrat from the Plant Breeding Research Center for Sustainable Agriculture, Faculty of Agriculture, Khon Kaen University is thanked for the waxy purple corn samples of byproducts. 


\section{REFERENCES}

[1] Abbas, M. N., Rana, S. A., Shahid, M., Rana, N., Mahmood-ul-Hassan, M., and Hussain, M. (2012). Chemical evaluation of weed seeds mixed with wheat grains at harvest. The Journal of Animal and Plant Sciences. 22(2), pp. 283-288.

[2] Al-Daihan, S., Al-Faham, M., Al-shawi, N., Almayman, R., Brnawi, A., Zargar, S., and Bhat, R. S. (December 2012). Antibacterial activity and phytochemical screening of some medicinalplants commonly used in Saudi Arabia against selected pathogenic microorganisms. Journal of King Saud University. 25,pp. 115-120. http://dx.doi.org/10.1016/j.jksus.2012.11.003

[3] Butkhup, L., Jeenphakdee, M., Jorjong, S., Samappito, S., Samappito, W., and Butimal, J. (April 2012). Phenolic composition and antioxidant activity of Thai and Eri silk sericins. Food Science and Biotechnology. 21(2), pp. 238-398. http://dx.doi.org/10.1007/s10068-012-0050-0

[4] Hong, S., Heo, J., Kim, J., Kwon, S., Yeo, K., Bakowska, A. M., Kolodziejczyk, P., Ryu, O., Choi, M., Kang, Y., Lim, S., Suh, H., Huh, S., and Lee, J. (July 2013). Antidiabetic and beta cell-protection activities of purple corn anthocyanins. Biomolecules and Therapeutics, 21(4), pp. 284-289.

http://dx.doi.org/10.4062/biomolther.2013.016

[5] Hosoda, K., Miyaji, M., Matsuyama, H., Haga, S., Ishizaki, H., and Nonaka, K. (May 2012). Effect of supplementation of purple pigment from anthocyanin-rich corn (Zea mays L.) on blood antioxidant activity and oxidation resistance in sheep. Livestock Science, 145 (1-3), pp. 266270.

http://dx.doi.org/10.1016/j.livsci.2011.12.001

[6] Kong, J.m Chia, L., Goh, N., Chia, T., and Brouillard, R. (November 2003). Analysis and biological activities of anthocyanins. Phytochemistry, 64, pp. 923-933. http://dx.doi.org/10.1016/S0031-9422(03)00438-2

[7] Li, C., Kim, H., Won, S., Min, H., Park, K., Park, J., Ahn, M., and Rhee, H. (November 2008). Corn husk as apotential source of anthocyanins. Journal of Agricultural and Food Chemistry, 56, pp. 11413-11416. http://dx.doi.org/10.1021/jf802201c

[8] Li, J., Lim, S. S., Lee, J., Kim, J., Kang, S., Kim, J., and Kang, Y. (April 2012). Purple corn anthocyanins dampened high-glucose-induces mesangial fibrosis and inflammation: possible renoprotective role in diabetic nephropathy. Journal of Nutritional Biochemistry, 23(4), pp. 320-331.

http://dx.doi.org/10.1016/j.jnutbio.2010.12.008

[9] Long, N., Suzuki, S., Sato, S., Naiki-Ito, A., Sakatani, K., Shirai, T., and Takahashi, S. (January 2013). Purple corn color inhibition of prostate carcinogenesis by targeting cell growth pathways. Cancer Science, 104(3), pp. 298-303. http://dx.doi.org/10.1111/cas.12078

[10] Pascual-Teresa, S. and Sanchez-Vallesta, M. T. (July 2008). Anthocyanins: from plant to health. Phytochemistry Reviews, 7(2), pp. 281-299. http://dx.doi.org/10.1007/s11101-007-9074-0

[11] Ramos-Escudero, F., Munoz, A. M., Alvarado-Ortiz, A. A., and Yanez, J. A. (February 2012). Purple corn (Zea mays L.) phenolic compound profile and its assessment as an agent against oxidative stress in isolated mouse organs. Journal of Medicinal Food, 15(2), pp. 206-215. http://dx.doi.org/10.1089/jmf.2010.0342

[12] Saerpoua, E., Tangwongchai, R., Suriharn, B., and Lertrat, K. (May 2013). Relationships between phytochemicals and antioxidant activity in corn silk. International Food Research Journal, 20(5), pp. 20732079.

[13] Saikaew, K., Tangwongchai, and Lertrat, K, "Colour parameters, total anthocyanins, and antioxidant activity at edible seed maturities of $K K U$-waxy purple corn," presented at the $13^{\text {th }}$ ASEAN Food Conference, Singapore. September 9-11, 2013.

[14] Santos, D. T., Cavalcanti, R. N., Rostagno, M. A., Queiroga, C. L., Eberlin, M. N., and Meireles, M. A. A. (2013). Extraction of polyphenols and anthocyanins from the Jambul (Syzygium cumini) fruit peels. Food and Public Health, 3(1), pp. 12-20. http://dx.doi.org/10.5923/j.fph.20130301.02

[15] Surh, Y.J. (March 1999). Molecular mechanisms of chemopreventive effects of selected dietary and medicinal phenolic substances. Mutation
Research Fundamental and Molecular Mechanisms of Mutagenesis, 428(2), pp. 305-327.

http://dx.doi.org/10.1016/S1383-5742(99)00057-5

[16] Thamaraiselvi, L. P., and Jayanthi, P. (2012). Preliminary studies on phytochemicals and antimicrobial activity of solvent extracts of Eichhornia crassipes (Mart.) Solms. Asian Journal of Plant Science and Research, 2(2), pp. 115-122.

[17] Usman, H., Abdulrahman, F. I., and Usman, A. (2009). Qualitative phytochemical screening and in vitro antimicrobial effects of methanol stem bark extract of Ficus thonningii (Moraceae). African Journal of Traditional, 6(3), pp. 289-295.

[18] Vinod, S. K., Raghuveer, I., Alok, S., and Himanshu, G. (2010). Phytochemical investigation and chromatographic evalution of the ethanolic extract of whole plant extract of Dendrophthoe falcata (L.F.) Ettingsh. International Journal of Pharmaceutical Sciences and Research, 1(1), pp. 39-45.

[19] Yang, Z., Chen, Z., Yuan, S., Zhai, W., Piao, X., and Piao, X. (December 2009). Extraction and identification of anthocyanin from purple corn (Zea mays L.). International Journal of Food Science and Technology, 44, pp. 2485-2492. http://dx.doi.org/10.1111/j.1365-2621.2009.02045.x

[20] Yang, Z. and Zhai, W. (January 2010). Identification and antioxidant activity of anthocyanins extracted from the seed and cob of purple corn (Zea mays L.). Innovative Food Science and Emerging Technologies, 11 , pp. 169-176. http://dx.doi.org/10.1016/j.ifset.2009.08.012

[21] Zhang, Q., Zhang, J., Shen, J., Silva, A., Dennis, D. A., and Barrow, C. J. (2006). A sample 96-well microplate method for estimation of total polyphenol content in seaweeds. Journal of Applied Phycology, 18, pp. 445-450.

http://dx.doi.org/10.1007/s10811-006-9048-4 